\begin{tabular}{|c|c|c|c|}
\hline TARAS & $\begin{array}{l}\text { Escola Superior } \\
\text { de Cestóoo } \\
\text { Tecnologia } \\
\text { [iPSantarém] }\end{array}$ & 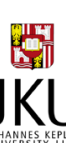 & $\begin{array}{l}\text { ISSN 2029-7564 (online) } \\
\text { SOCIALINĖS TECHNOLOGIJOS } \\
\text { SOCIAL TECHNOLOGIES } \\
2014,4(1) \text {, p. } 179-191\end{array}$ \\
\hline
\end{tabular}

\title{
SECURITY CONCERNS AND TRUST IN THE ADOPTION OF M-COMMERCE
}

\author{
Alexios Vasileiadis \\ Mykolas Romeris University, Lithuania, alexiosvas@gmail.com \\ doi:10.13165/ST-14-4-1-12
}

\section{Abstract}

Purpose - to deeply examine customer perception on how the determinants of trust and perceived risk affect their intention to adopt mobile commerce.

Design/methodology/approach - literature review, conceptual framework, modelling method, quantitative survey methodology (questionnaire instrument).

Findings - the perception of risk in terms of privacy, m-payments, $m$-commerce legislation and quality of delivered products has negative effect on the intention to adopt mobile commerce, good reputation of online vendors, enticing promises, good encryption security and transparency, reduces the effect of risk and increases the intention to use $m$-commerce. The availability of easy to understand and find policies has positive effect on the intention to use m-commerce. When customers feel free of risks and have high level of trust in the intention to use mobile commerce, they actually adopt it.

Research limitation/implications - this empirical research contributed to the theory by exploring the factors that influence or deter the adoption of $m$-commerce. However, the UTAUT model, simple random sampling method and case studies on how online vendors perform towards this topic are worth exploring by future researchers.

Practical implications - the research results show that mobile technology manufacturers and developers should improve both software and wireless network security, online vendors should improve their online reputation, transparency, and mobile website navigation. Lawmakers should improve $m$-commerce legislation to better protect customers in case of dispute with online vendors. 
Originality/value - previous researchers have never focused solely and in-depth on the determinants of perceived risk and trust. Moreover, this object had never been examined in the Greek Population.

Keywords: mobile commerce adoption, security concerns, trust, perceived risks.

Research type: literature review, conceptual paper, research paper.

\section{Introduction}

Nowadays, new technologies and communication channels emerge constantly and lead to new ways of conducting business. This situation influences businesses to restructure themselves by employing new tools in order to tailor to new markets or business trends. Needless to say that, today, consumers easily embrace all these new technologies and channels than in previous decades. In a nutshell, both businesses and consumers can take a number of advantages, such as having more convenient, faster and safer transactions than they used to have in the past. It is well-known that millions of people use smartphones and tablets to surf the internet for entertainment, information, purchasing of products and the like. For this reason, year in year out, the use of hand-held devices to purchase services or products on the go is constantly increasing. This is a great opportunity for e-businesses to take this situation under serious consideration and provide e-consumers with associated services such as Mobile Commerce not only to meet new consumer needs but also to be more competitive by increasing the offered value, entering new markets and generating more revenues.

This topic is intrigued by lots of authors and works that contributed not only to electronic but also mobile commerce. Nah and Davis (2002) examined e-commerce issues. Siau et al. (2003) developed a framework for trust in mobile commerce. Shon and Swatman (1997) investigated security perceptions for mobile payment systems. What is more, Amoroso and Hunsinger (2009) investigated consumer acceptance of online purchasing. Challeppa and Pavlou (2002) investigated consumer trust in e-commerce transactions (trust and risks). Clarke (2001) examined personal location as implications to risk and policy in new technologies. Culnan (1993) explored consumer attitude towards secondary use of information. Additionally, Gururajan (2002) examined new financial transaction security concerns in $\mathrm{m}$-commerce. Joubert and Belle (2013) investigated the role of trust and risk in the adoption of $\mathrm{m}$-commerce. Mahatanankoon et al. (2005) conducted a research on exploring consumer perception of mobile applications. Phelps et al. (2000) investigated privacy concerns and consumer willingness to provide personal information. Lastly, Swaminatha and Ghosh (2001) examined software security and privacy risks in $\mathrm{m}$-commerce communications.

After reviewing the literature, knowledge on the determinants of trust negatively affecting the perception of risk as well as the determinants of these two individual variables negatively or positively affecting the intention to adopt mobile commerce was still lacking. In order to solve the problem, an empirical study was performed. The author tested the developed hypotheses of a proposed research model based on 
TAM. The main objective was to analyse the data in order to confirm that security risks negatively affect the adoption of $\mathrm{m}$-commerce, while trust positively affects the adoption of m-commerce.

This paper is of both theoretical and practical importance. Due to in-depth examination of variables, such as customer perception of risk and trust attitude in the adoption of mobile commerce, the author generated new knowledge which helps not only future researchers to further investigate this context but also e-business to get an insight of how people react in mobile commerce security and trust factors.

Concerns about privacy, m-payments, lack of $\mathrm{m}$-commerce legislation, unanticipated product quality, unsecure networks and software, and the risk of unauthorised transactions drastically affect the online transaction process. Security concerns should be minimised while trust should be increased in order for $\mathrm{m}$-commerce to thrive.

\section{Theoretical Background}

\subsection{Security Concerns in M-Commerce Adoption}

According to Phelps et al. (2000) information privacy is an utmost security concern. However, Culnan (1993) found that concern over privacy might not affect consumer attitudes towards the use of secondary information. One of the biggest concerns is the possibility to compile a very detailed picture of someone's movements if they are carrying a wireless device that communicates its location to network operators (Ring and Van de Ven, 1992). Location-tracking of customers by mobile telephony providers via GSM, WLANs and GPS enabled services generates a need for addressing privacy issues in relation to the building of location-based technologies and services (Clarke, 2001). Moreover, not only the mobile device locations are tracked but also user preferences, so there is potential of high-proliferation and personalisation of the available data accordingly (Mahatanankoon et al., 2005). One way of building trust is for the e-businesses to provide users with privacy policy in order to inform them how and what for they are going to use the following elements: data user, data element, purpose of use, conditions and obligations (Steinfield, 2007). However, even though users are aware of the existence of privacy policy, they prefer not to read them because of their complexity and difficulty to understand. Plenty of individuals confuse security with privacy. For this reason, Joseph et al. (2012) have suggested that a need for governmental regulation over current privacy issues should be created or improved.

Security issues in electronic payment process have been extensively discussed in the literature. Chari (2001) claims that mobile commerce differs from e-commerce solutions due to differences in their technologies, because they create a number of new security exposures, e.g. mobile devices might be stolen, lost or damaged. It has also been demonstrated that people tend not to use their debit or credit card to proceed with transactions at a merchant with no good reputation (Challeppa, 2002). Hence, Friedman et al. (2000) strongly suggest businesses to improve their security and 
privacy issues for successful m-commerce. According to Shon and Swatman (1997), factors affecting the security perception of mobile payment systems adoption are reliability, privacy, anonymity, trustworthiness, regulatory framework and consumer protection. Generally, privacy and financial loss are of paramount importance to customers (Venkatesh and Kumar, 2012). Moreover, reliability of wireless services, such as encryption of wireless transaction data, authentication, wireless coverage area, and wireless communication can provoke security issues (Veijalainen, 2006). Besides the reliability of wireless services, one risk that can affect security in mobile devices is the hidden and unconscious computing, i.e. viruses, malware etc. In other words, device software (applications and platform) can be serious threats for user security and privacy (Swaminatha, 2001).

An emerging issue is the risk involving the intangible element of products and services offered by e-businesses to mobile customers (Gururajan, 2002). Research has shown that intangibility is positively correlated with perceived risk (De Ruyter et al., 2001). As e-customers cannot directly see or touch the offered products or services in the electronic market, they may feel anxiety or uncertainty when conducting online transactions with e-businesses. What is more, online customers may suffer the risk of paying expenses, such as shipping and handling when returning or exchanging a defective product or service.

$\mathrm{M}$-commerce is a rapidly developing area and the law may not be able to adapt to it as quickly as technology does. However, safeguards are already in place for consumers when it comes to online transactions. For example, vendors should be clear on how the new technology works and the implications for the customers. Governmental institutions play a fundamental role in establishing legislation and standards of services and they should constantly adapt it to the market development and new technologies in order to protect mobile consumers (Veijalainen, 2006).

\subsection{Trust in Adoption of M-Commerce}

Trust has played a crucial role in commercial relationships (Nah and Davis, 2002) and is a highly complex and multidimensional phenomenon (Lewis and Weigert, 1985). Trust in adoption of mobile commerce is influenced by a number of factors, such as reliability of wireless services, usability of m-commerce website, usability of mobile devices, information quality, privacy of customer information, security of mobile transaction, trustworthiness of product vendors, quality of product and effect of culture (Siau et al., 2003). Trust is important in situations that are perceived to be risky, and m-commerce as a relatively new field exposes mobile consumers to new vulnerabilities and risks (Joubert and Belle, 2013).

An important element of trust is institution-based trust. It is a person's feeling or belief that the environment in which they transact has appropriate safeguards and protections (Vance et al., 2008). All the principles of information security, such as confidentiality, integrity, availability, identification, authentication, authorisation, accountability, functionality, assurance, privacy and non-repudiation, can significantly affect both trusting beliefs and trusting intentions (Vance et al., 2008). There are a number of studies indicating that institution-based trust can strongly influence trust in online environments (Vance et al., 2008). 
System quality attributes are relevant to the concept of trust, because recent research suggests that technical aspects of IT artefacts affect users' willingness to trust. One can argue that security risks are closely related to trust. Trust is, in fact, a tacit component of many website quality studies (Vance et al., 2008).

Wang et al. (2006) also found strong support for the relationship between trust and ease of use. The logic for this relationship lies in the absence of better information. The ease of use increases $\mathrm{m}$-commerce engagement as well as the trust effect in this technology.

\section{Conceptual Framework}

After reviewing the literature, the author identified one dependent, one mediating and four independent variables. Table 1 shows an overview of the variables and Figure 1 shows the conceptual framework.

Table 1. Variables

\begin{tabular}{|l|l|l|}
\hline Independent Variables & Mediation Variable & Dependent Variable \\
\cline { 1 - 1 } Perceived Risk & \multirow{3}{*}{$\begin{array}{l}\text { Intention to Use } \\
\text { Trust }\end{array}$} & $\begin{array}{l}\text { Adoption of } \\
\text { M-commerce }\end{array}$ \\
\cline { 1 - 1 } Perceived Usefulness & & \\
\cline { 1 - 1 } Perceived Ease of Use & & \\
\hline
\end{tabular}

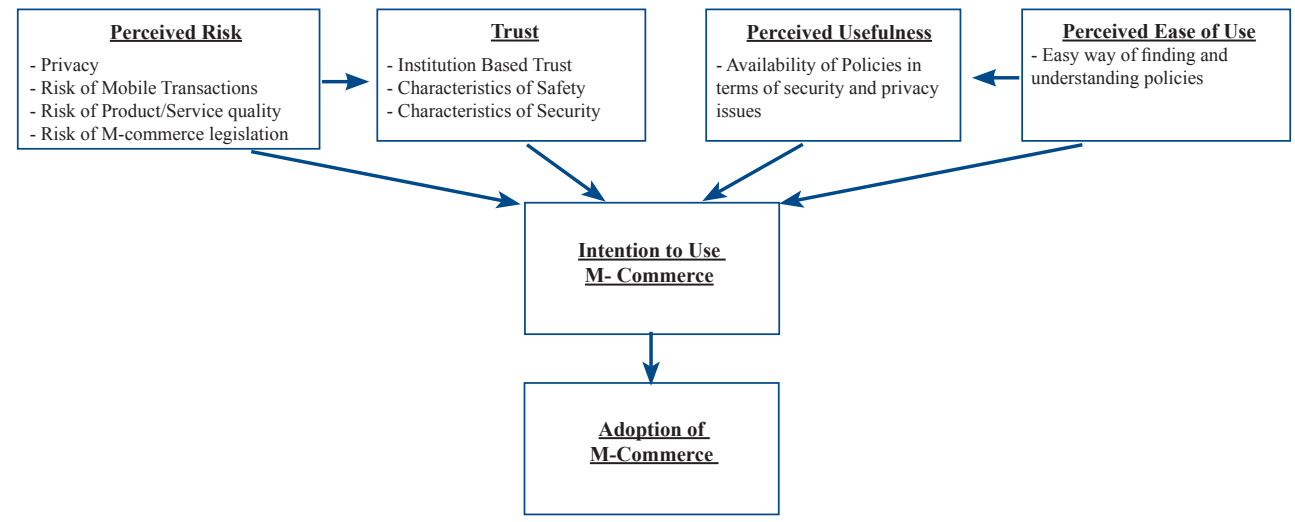

Figure 1. Conceptual Framework

\section{Research Design \& Methodology}

\subsection{Hypothesis Development}

The original Technology Acceptance Model (TAM) consists of Perceived Ease of Use (PEOU), Perceived Usefulness (PU), Behavioural Intention to Use (BI), and Actual System Use (AU). PEOU has been considered as an important determinant in 
the adoption of information technologies, such as m-commerce (Wang et al., 2006). $\mathrm{PU}$ is the extent to which someone believes that using an information system will enhance his or her performance (Davis et al., 1989). In this context, PU of getting policies is defined as the extent to which a consumer believes that a mobile device would enhance their effectiveness in getting information about policies. Perceived usefulness has been shown to shape positive attitudes in intention to use an IS (Taylor and Todd, 1995). Moreover, in TAM, an individual's intention to use a system is proposed to be a precursor of actual usage, that is, adoption of $\mathrm{m}$-commerce (Davis et al., 1989). From this standpoint, it is reasonable to hypothesise a significant relationship between perceived ease of use, perceived usefulness, intention to use and adoption of $\mathrm{m}$-commerce.

H1: Behavioural Intention to Use M-commerce has a direct positive effect on actual adoption of $\mathrm{M}$-commerce

H2a: Perceived Ease of Use has a direct positive effect on Intention to Use M-Commerce

H2b: Perceived Ease of Use has a direct positive effect on Perceived Usefulness

H3: Perceived Usefulness has a direct positive effect on Intention to Use M-Commerce

According to Amoroso and Hunsinger (2009), trust has been identified as a factor significantly influencing online purchasing. Trust is an important element affecting consumer behaviour and determining the success of e-commerce and $\mathrm{m}$-commerce technology adoption (Holsapple and Sasidharan, 2005). Trust is more crucial and complex in an environment such as e-commerce and $\mathrm{m}$-commerce than in general and traditional commerce due to its uncertain environment. By comparing electronic and mobile commerce, one researcher, $\mathrm{Lu}$ (2003), indicated that $\mathrm{m}$-commerce is exposed to greater danger of insecurity, so the importance of trust is relatively high in this context. What is more, this construct is a salient belief that includes goodwill trust and credibility (Pavlou, 2003). Last, but not least, according to Jarvenpaa et al. (2000) trust includes the antecedent of company's reputation. Based on these, the following hypothesis is proposed:

H4a: Trust has a direct positive effect on Intention to Use M-Commerce

According to Pavlou (2003), trust acts as an antecedent of perceived risk. Additionally, he indicates that trust in e-commerce or m-commerce can reduce a consumer's perception of risk regarding online transactions with a vendor. To further clarify, consumers in the web sphere are worried about risks concerning their personal information and monetary transactions (Luarn and Lin, 2005). Therefore, the following hypothesis is proposed:

H4b: Trust has a direct positive effect on Perceived Risk

There are plenty of studies supporting the integration of Perceived risk in TAM. In traditional commerce, perceived risk was related to fraud and inappropriate product quality. Nowadays, perceived risk refers to certain types of financial, product performance, physical, etc. when a client is proceeding with an online transaction. Moreover, since intention to use mobile commerce for transactions involves a certain degree of uncertainty, perceived risk is a direct antecedent of behavioural intention to 
use m-commerce. Pavlou (2003) includes perceived risk in TAM constructs. Therefore, the following hypothesis is proposed:

H5: Perceived Risk has a negative effect on Intention to Use M-Commerce

\subsection{Research Model}

The Technology Acceptance Model was chosen as the base of the research model by including two additional constructs, that is to say, Perceived Risk and Trust. Since TPB examines the constructs of behavioural control and social norm (Ajzen, 1991), and TRA (Fishbein and Ajzen, 1975) and TAM2 (Venkatesh and Davis, 2000) examine the construct of subjective norm, they were rendered inappropriate for this research. Moreover, UTAUT (Venkatesh et al., 2003) was excluded due to the fact that it is a highly complicated model for this context and it examines the construct of social influence. The new proposed model is illustrated in Figure 2 below:

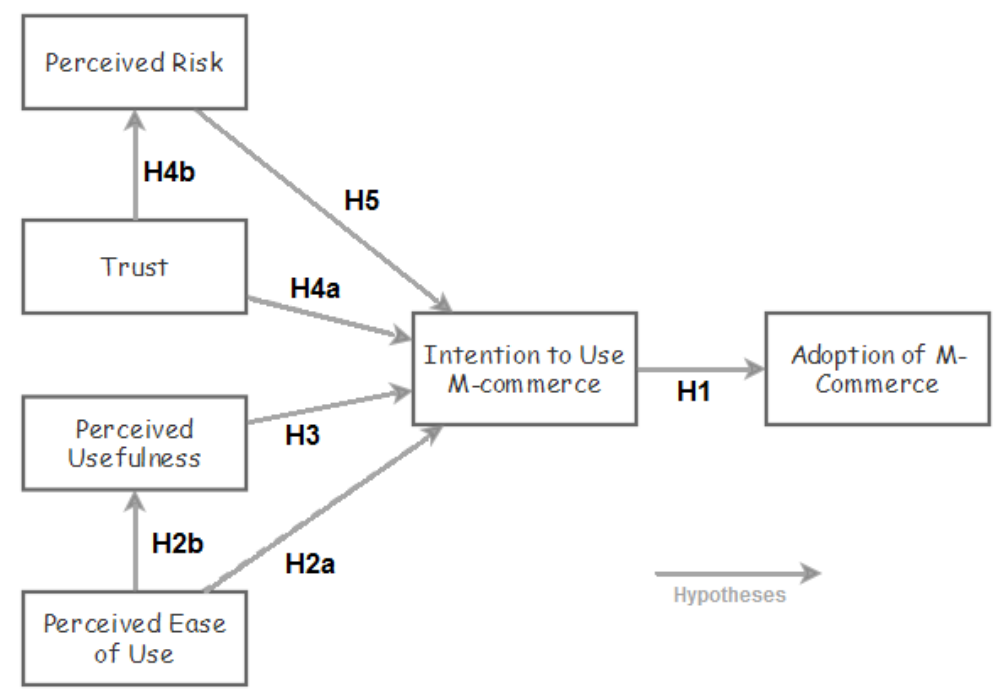

Figure 2. Proposed Research Model

\subsection{Methodology}

The quantitative approach was chosen in this paper because the ultimate goal was to examine costumer perception with regard to security concerns and trust in the intention to adopt mobile commerce by testing hypotheses (Ashley and Boyd, 2006). This approach put an effort to explain phenomena by providing results though with numbers (Lundahl and Skärvad, 1992) and finally generalising the results to the population (Bruns and Grove, 1987).

As for the research strategy, descriptive or survey instrument was chosen, because the purpose of this paper was to measure consumer response upon influential factors. It was also aimed at identifying the cause-effect between variables (Bruns and Grove, 1987) from one group of individuals and then generalising the results. 
When it comes to the data collection method, a questionnaire survey with 19 questions was used to test the cause-effect of variables as well as the proposed research model. The English and Greek version of the questionnaire can be found in Appendix $\mathrm{A}$ and $\mathrm{B}$ accordingly. Table 2 shows the relation between the created questions, variables and hypotheses.

Table 2. Survey questions, Hypotheses, Variables

\begin{tabular}{|l|l|l|}
\hline \multicolumn{1}{|c|}{ Variables } & Hypotheses & \multicolumn{1}{c|}{ Question Number } \\
\hline Perceived Risk & H5 & Q4, Q5, Q6, Q7, Q8, Q9, Q10Q11, Q12 \\
\hline Trust & H4a, H4b & Q13, Q14, Q15, Q16 \\
\hline Perceived Usefulness & H3 & Q17 \\
\hline Perceived Ease of Use & H2a, H2b & Q18 \\
\hline Adoption of M-commerce & H1 & Q19 \\
\hline
\end{tabular}

After having examined all the modes of survey administration, a face-to-face mode was chosen for a number of reasons. Initially, there should be visual aid, as the questions are associated with very specific terms. The researcher should also be present to clarify the meaning of some questions, as people would find it difficult to understand. The main goal was to achieve high rate of accurate responses.

According to Hellenic Statistical Authority (EL.STAT), in 2011, the Greek population amounted to approximately 10.815 .197 people. In addition, the same year, about $26.4 \%$ of the Greek population, namely, 2.855.212 individuals were using internet through a handheld device, such as a tablet, smartphone and the like ${ }^{1}$. Moreover, there were 1.889.916 people among the Greek population below 18 years of age who cannot use credit cards. To sum up, the population for this study consisted of 965.296 people.

Cochran's formula was used (Cochran, 1977) to determine the sample size. The confidence level was $95 \%$, the confidence interval was $11 \%$ and the population was 965.296 people. The result of this equation was a minimal sample size of 79 respondents in order to have a sample that is strong enough.

Probability sampling is the ideal technique to be used when a researcher aims to generalise the results of the study, while non-probability sampling is not an appropriate group of techniques to achieve this aim (Bhattacherjee, 2012). To delve into details, cluster sampling method was used, because it was not economically affordable to conduct a simple random sampling of the entire population. For this reason, the sample includes three clusters, namely Athens, Thessaloniki and Serres (the cities that makes about half of the total Greek population).

In order to accurately measure theoretical constructs of this study, an operationalisation process was needed. In this study, there were two multidimensional constructs, such as trust and perceived risk, as well as three unidimensional constructs, such as perceived usefulness, perceived ease of use, and adoption of m-commerce.

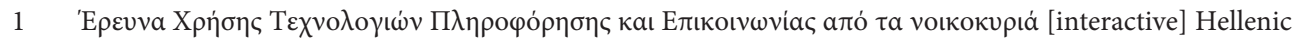
Statistical Authority, 2011. [Accessed on 2013-10-10]. <www.statistics.gr/portal/page/portal/ESYE/ BUCKET/A1901/PressReleases/ A1901SFA20_DT_AN_00_2012_01_F_GR.pdf> 
In multidimensional constructs, each underlying dimension should be measured separately and afterwards the scores should be combined to create an overall value for a specific multidimensional construct (Bhattacherjee, 2012). The author measured and operationalised the constructs through indicators using Likert Scale attributes (5 scales).

\section{Results and Findings}

This survey was distributed from 7 to 14 October 2013. In total, 169 out of 215 respondents completed the survey by answering the given questionnaire. However, due to the fact that some respondents omitted to answer some questions or double answered some items, 9 questionnaires were excluded. In other words, the total amount of valid responses was 160 , that is to say, twice as many as the minimum determined sample size.

In order to accurately measure the constructs, an operationalisation method was used to provide score means from 1 to 5 , with 1 totally rejecting the proposed hypothesis and 5 totally accepting the proposed hypothesis. In other words, when the total mean score of each construct is above 2.5 it validates the stated hypothesis, while below 2.5 it rejects the stated hypothesis.

Table 3. Univariate Analysis Results

\begin{tabular}{|l|l|c|c|l|}
\hline Hypothesis & \multicolumn{1}{|c|}{ Construct } & $\begin{array}{c}\text { Score } \\
\text { Mean }\end{array}$ & $\begin{array}{c}\text { Standard } \\
\text { Deviation }\end{array}$ & $\begin{array}{c}\text { Univariate } \\
\text { Analysis }\end{array}$ \\
\hline H1 & Adoption of M-commerce & 4.269 & 0.963 & $\underline{\text { Accepted }}$ \\
\hline H2a, H2b & Perceived Ease of Use & 4.200 & 0.937 & $\underline{\text { Accepted }}$ \\
\hline H3 & Perceived Usefulness & 4.327 & 0.838 & $\underline{\text { Accepted }}$ \\
\hline H4a, H4b & Trust & 4.108 & 0.971 & $\underline{\text { Accepted }}$ \\
\hline H5 & Perceived Risk & 3.440 & 1.152 & $\underline{\text { Accepted }}$ \\
\hline
\end{tabular}

As we can see in Table 3, the total Score Mean for the perceived risk construct is 3.440 and is defined as the respondents having neutral toward negative intention to use mobile commerce when risk factors exist. Moreover, the total Score Mean for the trust construct is 4.108 . This score indicates that respondents have positive intention to use mobile commerce when the described trust factors are associated with risks. What is more, the result of perceived usefulness construct, that is 4.327 , show us that it has a direct positive effect on intention to use $\mathrm{m}$-commerce. The score mean of perceived ease of use was 4.200, meaning it has a positive effect on perceived usefulness. Last, the mean score of H1, that is, 4.269 shows that behavioural intention to use $\mathrm{m}$-commerce has a direct positive effect on actual adoption of $\mathrm{m}$-commerce. Below there is a summary of the accepted hypotheses. 
Table 4. Hypotheses \& Definitions

\begin{tabular}{|c|c|c|}
\hline No. & Hypothesis Definition & $\begin{array}{l}\text { Univariate } \\
\text { Analysis }\end{array}$ \\
\hline H1 & $\begin{array}{l}\text { Behavioural Intention to Use M-commerce has a direct effect on actual } \\
\text { adoption of M-commerce }\end{array}$ & Accepted \\
\hline $\mathrm{H} 2 \mathrm{~b}$ & Perceived Ease of Use has a direct positive effect on Perceived Usefulness & Accepted \\
\hline H2a & $\begin{array}{l}\text { Perceived Ease of Use has a direct positive effect on Intention to Use } \\
\text { M-Commerce }\end{array}$ & Accepted \\
\hline H3 & $\begin{array}{l}\text { Perceived Usefulness has a direct positive effect on Intention to Use } \\
\text { M-Commerce }\end{array}$ & Accepted \\
\hline H4a & Trust has a direct positive effect on Intention to Use M-Commerce & Accepted \\
\hline H4b & Trust has a direct positive effect on Perceived Risk & Accepted \\
\hline H5 & Perceived Risk has a negative effect on Intention to Use M-Commerce & Accepted \\
\hline
\end{tabular}

\section{Conclusions}

The results have showed that the perception of risk in terms of privacy, m-payments, legislation and product quality deters customers from using mobile commerce. As for privacy, customers are disappointed when their current location and internet habits are revealed to online vendors and the latter are using the above data to better market the offered products or services. Moreover, customers have negative intention to use $\mathrm{m}$-commerce to proceed with mobile payments as they feel the risk of unauthorised transaction in the case the device is lost or stolen, the wireless network, operating system and mobile application is unsecured. What is more, the perception of risk about the quality of the delivered product might not be as it was anticipated as well as the fear of not being protected by mobile commerce legislation has a negative effect on the intention to use m-commerce.

Contrarily, it was shown that the determinant of trust reduces the perception of risk in the intention to use m-commerce, namely, when an online vendor has good reputation, offers good encryption security, transparency on how the data are going to be used, enticing promises, guarantees and contracts in case of dispute, customers place trust on the vendor and have strong intention to use $\mathrm{m}$-commerce.

Moreover, the analysis indicates that perceived usefulness of getting policies in terms of fraud protection, privacy and return of a delivered product has a direct positive effect on the intention of customers to use $\mathrm{m}$-commerce.

In addition, customers prefer to find easy and comprehendible existent fraud protection, privacy and return policies in order to have intention to use $\mathrm{m}$-commerce. The last conclusion of this research is the fact that when customers feel free of risks and have high level of trust in the intention to use mobile commerce, they actually are able to adopt it.

There are plenty of recommendations that should be adopted by mobile technology manufacturers, software developers, online vendors and lawmakers. First 
and foremost, there is a need for more secure software and wireless networks. As for online vendors, they should focus on improving not only their online reputation, but also their $\mathrm{m}$-commerce websites or applications in terms of trust. In addition, online merchants should include all the necessary policies with regards to privacy, return and fraud protection policies that are not only easy to find in $\mathrm{m}$-commerce website and application but also easy to understand. Lawmakers should also focus on improving $\mathrm{m}$-commerce legislation to better protect customers in case of dispute with online vendors.

The conclusions proved the novelty of this paper as there was no in-depth discussion on how specific determinants can affect the actual adoption of $\mathrm{m}$-commerce. However, the effects of subjective norm, performance, effort expectance, social influence, experience, gender, age and voluntariness of use for the adoption of $\mathrm{m}$-commerce in terms of perceived risk and trust should be further examined. Future researchers can further investigate this topic by adjusting determinants in UTAUT model. Moreover, due to the fact that cluster sampling technique was used, the results are not $100 \%$ generalisable to the Greek population. In order to achieve this, simple random sampling method of the entire population is necessary. The last limitation was to examine how online vendors are performing towards that topic to meet customer needs through case studies.

\section{References}

\section{Books and articles:}

Ajzen, I. 1991. The Theory of Planned Behaviour. Organizational Behaviour and human decision processes, 50: 179-211.

Amoroso, D.L.; Hunsinger, D.S. 2009. Understanding consumers' acceptance of online purchasing. Journal of Information Technology Management, 10(1): 15-41.

Ashley, P.; Boyd, P. 2006 Quantitative and Qualitative Approaches to Research in Environmental Management. Australasian Journal of environmental management, 13(2): 70-78.

Benbasat, I. et al. 2005. Trust and adoption of online recommendation agents. Journal of the AIS, 6(3): 75-101.

Bhattacherjee, A. 2012. Social Science Research: Principles, Methods, and Practices. Florida: Global Text Project.

Bruns, N.; Grove, S.K. 1987. The practice of research, conduct, critique, and utilization. Saunders.
Challeppa, R.K.; Pavlou, P. 2002. Perceived Information Security, Financial Liability, and Consumer Trust in Electronic Commerce Transactions. Journal of Logistics Information Management, 15(5/6): 358-368.

Chari, S. et al. 2001. Security Issues in M-Commerce: A Usage-Based Taxonomy. Proceeding E-Commerce Agents, Marketplace Solutions, Security Issues, and Supply and Demand. Berlin:Heidelberg p. 264-282.

Clarke, R. 2001. Person location and person tracking - Technologies, risks and policy implications. Information technology and People, 14(2): 206-231.

Cochran, W. G. 1977. Sampling Techniques. Canada: John Wiley \& Sons.

Culnan, M.J. 1993. How Did They Get My Name? An Exploratory Investigation of Consumer Attitudes toward Secondary Information Use. MIS Quarterly, 17(3): 341-363. 
Davis, F. et al. 1989. User acceptance of computer technology: A comparison of two theoretical models. Management Science, 35(8): 982-1003.

De Ruyter, K. et al. 2001. Customer Adoption of E-service: An Experimental Study. International Journal of Service Industry Management, 12(2): 184-207.

Fishbein, M.; Ajzen, 1975. Belief, attitude, intention, and behaviour: An Introduction to Theory and Research, Massachusetts: Addison-Wesley Pub.

Friedman, B. et al. 2000. Trust Online. Communications of the ACM, 43(12): 34-40.

Gururajan, R. 2002. New Financial Transaction Security Concerns in Mobile Commerce. Information \& Security: An International Journal, 8(1): 71-86.

Holsapple, C.W.; Sasidharan, S. 2005. The dynamics of trust in online B2C e-commerce: a research model and agenda. Information Systems and E-business Management, 3(4): 377-403.

Jarvenpaa, S.L. et al. 2000. Consumer trust in an Internet store. Information Technology Management, 1(1-2): 45-71.

Joubert, J.; Belle, J.-P. 2013. The Role of Trust and Risk in Mobile Commerce Adoption within South Africa. International Journal of Business, Humanities and Technology, 3(2): 27-38.

Lewis, J.; Weigert, A.; 1985. Trust as a social reality. Social Forces, 63(4): 967-985.

Liu, Y. et al. 2006. Enabling Technologies for Wireless E-Business. Berlin: Springer Berlin Heidelberg.

Lu, J. et al, 2003 Technology acceptance model for wireless internet. Internet Research: Electronics Networking Applications and Policy, 13(3): 206-222.

Luarn, P.; Lin, H.H. 2005. Toward an understanding of the behavioral intention to use mobile banking. Computer in Human Behaviour, 21(6): 873-891.

Lundahl, U.; Skärvad, P.H. 1992. Utredningsmetodik för samhällsvetare och ekonomer, 2 edtition. Sweden: Studentlitteratur.
Mahatanankoon, P. et al. 2005. Consumerbased m-commerce: exploring consumer perception of mobile applications. Computer Standards \& Interfaces, 27(4): 347-357.

Nah, F.; Davis F. 2002. HCI Research Issues in Electronic Commerce. Journal of Electronic Commerce Research, 3(1): 98-113.

Pavlou, P.A. 2003. Consumer acceptance of electronic commerce: integrating trust and risk with the technology acceptance model. International Journal of Electronic Commerce, 3(1): 101-134

Phelps, J. et al. 2000. Privacy Concerns and Consumer Willingness to Provide Personal Information. Journal of Public Policy and Marketing, 19(1):27-41

Shon, T.H.; Swatman, P.M.C. 1997. Effectiveness criteria for internet payment systems. Proceedings of "PAWEC'97", the 1st Pacific Asia Workshop on Electronic, 7: 1-18.

Siau, K. et al. 2003. Development of a Framework for Trust in Mobile Commerce. Proceedings of the Second Annual Workshop on HCI Research in MIS. Washington: Seatle, p. 85-89.

Steinfield, C. 2004. The development of location based services in mobile commerce. Heidelberg: springer publishing company.

Swaminatha, T.M.; Ghosh, A.K. 2001. Software security and privacy risks in mobile e-commerce. Communications of the ACM, 44(2): 51-57.

Taylor, S.; Todd, P. 1995. Understanding Information Technology Usage: A Test of Competing Models. Information System Research, 6(2): 144-176.

Vance, A. et al. 2008. Examining Trust in Information Technology Artifacts: The Effects of System Quality and Culture. Journal of Management Information Systems, 24(4): 73-100.

Veijalainen, J. 2006. Mobile Commerce Regulatory Frameworks under Digital Convergence, Proceedings of Helsinki Mobility Roundtable, 6(55): 1-12.

Venkatesh, J.; Kumar, S.D. 2012. Evaluation of mobile payment system and its service providers. International Journal of Multidisciplinary Research, 2(4): 118-123. 
Venkatesh, V.; Davis, F. 2000. A Theoretical Extension of the Technology Acceptance Model: Four Longitudinal Field Studies. Management Science, 46(2): 186-204.

Venkatesh, V. et al. 2003. User Acceptance of Information Technology: Toward a Unified View. Management Information Systems Quarterly, 27(3): 425-478.

Wang, Y.S. et al. 2006. Predicting consumer intention to use mobile service. Information Systems Journal, 16(1): 157-179.

Internet sites:

Joseph, D. B. et al. 2012. An Analysis of Web Privacy Policies across Industries [interactive]. Worcester Polytechnic Institute [Accessed on 2013-09-25] <https:// www.wpi.edu/Pubs/E-project/Available/Eproject-121412-121246/unrestricted/IQP Final_Report.pdf>.

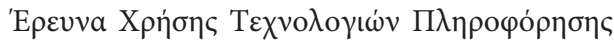

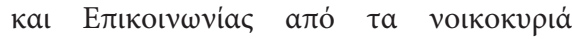
[interactive]. Hellinic Statistical Authority, 2011. [Accessed on 2013-1010]. <www.statistics.gr/portal/page/portal/ ESYE/BUCKET/A1901/PressReleases/ A1901SFA20_DT_AN_00_2012_01_F_ GR.pdf> 